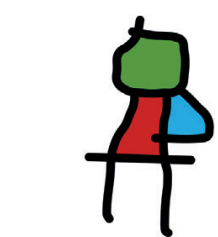

SEICAIP

\section{Allergologia et immunopathologia}

Sociedad Española de Inmunología Clínica, Alergología y Asma Pediátrica

www.all-imm.com

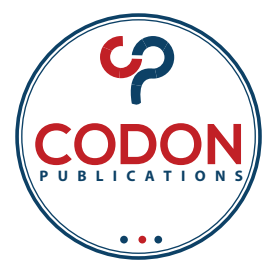

ORIGINAL ARTICLE

OPEN ACCESS ㄷㅇ(1) (2)

\title{
Bioavailability assessment of fexofenadine and montelukast in a fixed-dose combination tablet versus the components administered simultaneously
}

\section{Everardo Piñeyro-Garzaa*, Magdalena Gómez-Silva ${ }^{a}$, Maria Elena Gamino-Peñaa Vanessa Cohen-Muñoz ${ }^{b}$, Gabriela Sánchez-Casadob}

alpharma, S.A. de C.V., Monterrey, Mexico

${ }^{b}$ Medical Department, Consumer Health Care, Sanofi, Ciudad de México, Mexico

Received 24 November 2020; Accepted 17 March 2021

Available online 1 July 2021

\section{KEYWORDS \\ fexofenadine; montelukast; bioequivalence; allergic rhinitis; antihistamine- antileukotriene; fixed-dose combination}

\begin{abstract}
Introduction and Objectives: Allergic rhinitis is a condition with high global prevalence most effectively treated with antihistamines and antileukotrienes. This study aimed to evaluate the bioequivalence of fexofenadine and montelukast in a fixed-dose combination tablet versus the components administered simultaneously.

Materials and Methods: An open, randomized, $2 \times 2$ crossover study was performed in 78 healthy volunteers. Fexofenadine-montelukast tablets containing $120 \mathrm{mg}$ and $10 \mathrm{mg}$, respectively, were used as the test treatment, and $120 \mathrm{mg}$ fexofenadine tablets and $10 \mathrm{mg}$ montelukast tablets were used as the reference treatment. Concentrations of fexofenadine and montelukast in plasma were determined by protein precipitation and analysis by liquid chromatography/mass spectrometry or liquid chromatography tandem mass spectrometry.

Results: The $90 \%$ confidence intervals (Cls) obtained for fexofenadine were 87.612-102.144 for area under the curve of the plasma concentration after administration to the last concentration $\left(A \cup C_{0-\mathrm{t}}\right), 88.471-102.282$ for the AUC of the plasma concentration extrapolated to infinity $\left(\mathrm{AUC}_{0-\infty}\right)$, and 91.413-108.544 for the maximum plasma concentration $\left(\mathrm{C}_{\max }\right)$. For montelukast, they were 96.418-108.416 for $A U C_{0-\mathrm{t}}$, 93.273-106.642 for $\mathrm{AUC}_{0-\infty}$ and 94.749-110.178 for $\mathrm{C}_{\max }$. The ratio and $\mathrm{Cls}$ of the values subjected to logarithmic transformation for each parameter were within the range of acceptability of $80 \%-125 \%$, demonstrating the bioequivalence of the combined fixed-dose tablet to the components administered separately at the same doses. No adverse events were recorded during the study.

Conclusions: This study has shown the bioequivalence of the combined fixed-dose tablet, which may be considered a new alternative for the treatment of allergic rhinitis.

(c) 2021 Codon Publications. Published by Codon Publications.
\end{abstract}

${ }^{*}$ Corresponding author: Everardo Piñeyro-Garza. Ipharma, S.A. de C.V., Celaya 322, Mitras Centro, 64460 Monterrey, N.L., Mexico. Email address: epineyro@i-pharma.com.mx 


\section{Introduction}

Allergic rhinitis, whether seasonal or perennial, is a condition with a high global prevalence that can affect between $10 \%$ and $30 \%$ of adults and up to $40 \%$ of children, ${ }^{1}$ thus generating an economic and social burden.

In the pathophysiology of allergic rhinitis, histamine and cysteinyl leukotrienes (CysLTs) increase vascular permeability and resistance to nasal flow, causing symptoms, such as rhinorrhea, nasal itching, and sneezing (among others), which are associated with an increased risk of nasal congestion and reductions in quality of life and productivity. ${ }^{2-4}$

The Allergic Rhinitis and its Impact on Asthma Guidelines (ARIA) recommend managing allergic rhinitis with various treatments, including second-generation antihistamines (histamine type $1, \mathrm{H}_{1}$ ) and leukotriene receptor antagonists. ${ }^{3,4}$

Fexofenadine, the active metabolite of terfenadine, is a selective antagonist of the $\mathrm{H}_{1}$ receptor that does not cross the blood-brain barrier and has anti-inflammatory properties. It is rapidly absorbed with a long-lasting effect and can therefore be administered once daily for the treatment of allergic rhinitis.,

Montelukast is an antagonist of the CysLT type 1 receptor, and its anti-inflammatory effect is exploited to treat seasonal and perennial allergic rhinitis. ${ }^{4}$

Antihistamines and antileukotrienes are frequently used in combination for the treatment of allergic rhinitis because histamine and CysLTs have different roles in the pathophysiology of allergic rhinitis, and antihistamine-antileukotriene therapy has been shown to be more effective than monotherapy due to simultaneous blockade of two mediators with complementary effects, thereby effectively reducing symptoms. ${ }^{2,7,8}$ In addition, therapeutic adherence is an important factor in the optimal management of allergic rhinitis, and administration of a fixed-dose combination of an antihistamine with an antileukotriene can improve this condition. ${ }^{3}$

The addition of montelukast to treatment with $\mathrm{H}_{1}$ antihistamines has been assessed in multiple clinical trials, demonstrating additional advantages compared with monotherapies. , $, 9,10$ In particular, the fixed-dose combination of fexofenadine with montelukast has been used to treat allergic rhinitis and has demonstrated efficacy and safety.

A fixed-dose combination tablet containing fexofenadine $120 \mathrm{mg}$ and montelukast $10 \mathrm{mg}$ was developed with the aim of offering a new therapeutic alternative to improve treatment adherence and convenience for patients with allergic rhinitis. The objective of this study was to evaluate the bioequivalence of the fixed-dose combination tablet and simultaneous administration of each compound at the same doses and at the same time in healthy volunteers under fasting conditions.

The study was carried out in the facilities of Ipharma S.A. de C.V. following the protocol A473-18 authorized by the research committee $16 \mathrm{Cl} 19039043$ and by the Mexican Ministry of Health (COFEPRIS) 183301410B0368/2018.

\section{Materials and Methods}

Healthy volunteers (men and women) between 18 and 55 years of age, with body mass index (BMI) between 18 and $27 \mathrm{~kg} / \mathrm{m}^{2}$, were included in the study. The volunteers had negative results for pregnancy tests (women) and for exams assessing substance abuse during selection and at the beginning of each test period of study. Volunteers also had negative results for tests detecting anti-HIV antibodies (HIV Ag), Australia surface antigens for hepatitis B (HBsAg), anti-hepatitis $\mathrm{C}$ antibodies ( $\mathrm{HCV} \mathrm{Ag),} \mathrm{and} \mathrm{the} \mathrm{rapid} \mathrm{plasma}$ reagin (RPR) test.

The volunteers were required to have the following biochemical test results within the normal ranges: complete blood count, urinalysis, and biochemical profile. Additionally, their electrocardiograms could not show any abnormalities.

The exclusion criteria were drug allergies, intolerance to venipuncture, tobacco abuse (more than five cigarettes per day), currently receiving medical treatment, breastfeeding, swallowing or phagophobia problems, a history of asthma, drug addiction or alcohol abuse, having received a vaccine in the past 2 weeks, and consumption of more than five cigarettes, alcoholic beverages, xanthine-containing drinks, grapefruit juice, foods prepared on charcoal, food supplements, herbal remedies, or other drugs (phenytoin, magnesium hydroxide, or aluminum) in the past 48 hours.

\section{Sample size calculation}

Assuming a true ratio of $95 \%$ and an intrasubject variability of $35.08 \%, 12,13$ a sample size of 70 subjects was required to conclude comparative bioavailability between the two products with a power of $90 \%$. After accounting for dropouts, it was decided to enroll 78 subjects, including 49 females and 29 males whose characteristics met the criteria to define a homogenous population according to the current norm, the protocol, and good clinical practices.

The number of subjects required for this comparative bioavailability study (sample size) was selected as established in the literature to determine the intrasubject variability (intrasubject $C V$ ) of the $A U C$ and $C_{\max }$ values from previous studies published for the same substances. The sample size was also selected according to the criteria established in the Mexican official standard NOM-177SSA1-2013 for the administration of a single dose of a drug to healthy volunteers. Feeding variables were controlled to avoid effects from the consumption of food ${ }^{14}$ or substances (alcohol or drugs).

\section{Study design}

An open, randomized, $2 \times 2$ crossover study with two treatments applied over two periods at a single dose and two sequences under fasting conditions was conducted in January and February 2019. The analysts were blinded to the test $(T)$ and reference (R) group assignments.

The study was conducted in accordance with applicable Mexican laws and regulations and adhered to good clinical practice (ICH 6), good documentation practices, and other regulatory provisions applicable in Mexico. 
Each medication was administered to each volunteer only once because the duration of action is sufficiently long to measure pharmacokinetic parameters. Each volunteer's commitment was approximately 21 days. The treatment was administered during two periods of hospitalization for 37 hours, and two samples were collected at 48 and 72 hours after discharge. A 7-day washout period was implemented to ensure compliance with the norm establishing a seven-half-life period for the drug.

\section{Administration of the drugs}

Fexofenadine-montelukast tablets containing $120 \mathrm{mg}$ and $10 \mathrm{mg}$, respectively (lot $8 \mathrm{MXA001}$, expiration date: April 2, 2020, manufactured by Sanofi-Aventis de Mexico, S.A. de C.V.), were used as the test treatment (T). As the reference treatment (R), 120-mg fexofenadine tablets (Allegra ${ }^{\circledR}$, lot 8MXA003, expiration date: December 29, 2019, manufactured by Sanofi-Aventis Farmacéutica Ltd. and distributed by Sanofi-Aventis de Mexico, S.A. de C.V.) and 10-mg montelukast tablets (Singulair ${ }^{\circledR}$, lot R007030, expiration date: January 31, 2020, manufactured by Merck Sharp \& Dohme Ltd. and distributed by Schering-Plough, S.A. de C.V.) were used. See Supplementary Material 1 for additives used in tablet formation.

After a fast of at least 10 hours, baseline samples were collected, and then a 120-mg/10-mg fixed-dose fexofenadine-montelukast tablet was administered or the two individual drugs (fexofenadine $120 \mathrm{mg}$ and montelukast $10 \mathrm{mg}$ ) were administered simultaneously dependent on previous randomization ( $\mathrm{T}$ or $\mathrm{R}$ ). The drugs were taken orally with $250 \mathrm{~mL}$ of room-temperature water.

Random group assignment was performed in two blocks under a balanced design such that half of the subjects were assigned to the RT administration sequence and the remaining subjects were assigned to the TR sequence. Random assignment was performed using the software $\mathrm{R}^{15}$ with its internal algorithm Mersenne Twister, which has been previously validated with the DIEHARD test set for the assessment of random number generators.

\section{Sampling}

A venous catheter was placed in a vein selected by the phlebotomist to facilitate the collection of subsequent samples. In each period, 22 4-mL samples were collected from each volunteer, including a sample at time 0.00 (predose) and samples at 0.33, 0.66, 1.00, 1.33, 1.66, 2.00, 2.33, 2.66, 3.00, 3.33, 3.66, 4.00, 4.5, 5.0, 6.0, 8.0, 10.00, $12.00,24.00,48.00$, and 72.00 hours. EDTA was added to each sample as an anticoagulant.

Each test tube was marked with a unique key for each subject, the consecutive number of the subject from 1 to 78 , the period of study ( $\mathrm{T} 1$ or $\mathrm{T} 2$ ), and the number corresponding to the sample collection time (01 to 22). The medication ( $\mathrm{T}$ or $\mathrm{R}$ ) was not indicated.

The samples were sent to an analytical laboratory for centrifugation at 3000 RPM for 10 minutes at a temperature of $5^{\circ} \mathrm{C}$. The samples were then fractioned and immediately frozen.

\section{Analytical methods}

Analyses were performed via precipitation of proteins, with subsequent analyses by liquid chromatography/mass spectrometry (HPLC/MS) or liquid chromatography tandem mass spectrometry (HPLC/MS-MS). The FXF-esi-MRM.m method for fexofenadine-montelukast and the MTKS.M, developed by the company Ipharma and validated with the official Mexican standard NOM-177-SSA 1-2013, were used. The concentration ranged from $5 \mathrm{ng} / \mathrm{mL}$ to $1000 \mathrm{ng} / \mathrm{mL}$ for both drugs.

\section{Pharmacokinetic analysis}

The pharmacokinetic parameters measured were the time to reach the maximum plasma concentration $\left(T_{\max }\right)$, the maximum plasma concentration $\left(C_{\max }\right)$, the area under the curve of the plasma concentration after administration to the last concentration observed $\left(\mathrm{AUC}_{0-\mathrm{t}}\right)$, the area under the curve of the plasma concentration extrapolated to infinity $\left(\mathrm{AUC}_{0-\infty}\right)$, the elimination constant $\left(\mathrm{K}_{\mathrm{e}}\right)$, and the elimination half-life $\left(\mathrm{t}_{1 / 2}\right)$. The parameters assessed to establish possible equivalence in bioavailability were the $\mathrm{C}_{\max }$ and $\mathrm{AUC}_{0-\mathrm{t}^{*}}$.

The pharmacokinetic parameters were determined with Phoenix WinNonlin 8.1 software. The range for acceptance of bioequivalence for both substances is $80 \%$ to $125 \%$ ( $90 \%$ confidence intervals $[\mathrm{Cl}]$ of the geometric means of the $T / R$ ratios for the $C_{\max }$ and $A U C_{0-t}$ after logarithmic transformation).

\section{Analysis of safety}

During the study and the sampling periods, the volunteers underwent a general physical examination protocol to assess the following vital signs: respiratory rate, body temperature, blood pressure, and heart rate. They were also monitored for the occurrence of adverse events.

\section{Analysis of tablet stability}

Stability tests including for weight, uniformity, disintegration, and identification were performed. See Supplementary Material 2 for full list of tests and parameters.

\section{Statistical analysis}

The $A U C_{0-t}, A U C_{0-\infty}, C_{\max }, K_{e}, t_{1 / 2}$, and $T_{\max }$ were estimated using a noncompartmental model; the $A U C_{0-t}$ and $A U C_{0-\infty}$ were estimated using the linear-logarithmic trapezoidal method, while the $C_{\max }$ and $T_{\max }$ were obtained directly from the decoded data. Descriptive statistics were calculated from the pharmacokinetic parameter values. Subsequently, the logarithmically transformed $\mathrm{AUC}_{0 \text {-t }}$, $\mathrm{AUC}_{0-\infty}$, and $\mathrm{C}_{\max }$ values were subjected to analysis of variance (ANOVA) to assess the possible effects of factors that could influence the response variables. The fixed factors included in this model were the sequence, the treatment 
(formulation), the period, and the subject nested within sequence as random effect. The sequence, period, and treatment effects were assessed at the 5\% two-sided significance level. Furthermore, the $\mathrm{Cl}$, test power, and unilateral double Schuirmann $t$-test results were assessed. ${ }^{16-19}$ Statistical analysis was performed without subjects with extreme values. The statistics used to evaluate comparative bioavailability were calculated using Phoenix WinNonlin 8.1 software.

This comparative bioavailability study was conducted following the guidelines outlined in the Mexican Official Standard NOM-177-SSA1-2013, which establishes tests and procedures used to demonstrate that a drug is interchangeable, requirements to which authorized third parties who carry out interchangeability tests must adhere, requirements for carrying out biocompatibility studies, and requirements to be considered by authorized third parties, research centers, or hospital institutions that conduct biocompatibility tests.

\section{Results}

\section{Population}

A total of 78 healthy volunteers were included in the study. Only one volunteer did not show up for the second period of hospitalization and was excluded according to the elimination criteria. The demographic characteristics of the 77 volunteers assessed in the study are presented in Table 1.
Data from the 77 volunteers who completed the study according to the protocol were used to calculate the pharmacokinetic parameters $\mathrm{T}_{\max }, \mathrm{C}_{\max }, \mathrm{AUC}_{0-\mathrm{t}}, \mathrm{AUC}_{0-\infty}, \mathrm{K}_{\mathrm{e}}$, and $t_{1 / 2}$, with the concentrations measured in relation to the time profiles for fexofenadine and montelukast. The results are presented in Table 2

In Tables 3 and 4, 90\% Cls are presented for the $\mathrm{AUC}_{0-\mathrm{t}}$, $\mathrm{AUC}_{0-\infty}$, and $\mathrm{C}_{\max }$ of fexofenadine and montelukast. For both drugs, the Cls of the three parameters are within the bioequivalence range of $80 \%$ to $125 \%$ established in the protocol.

The ANOVA results revealed no statistically significant effect on the administration sequence, the administration period, or the formulation. For the sequence factor, for fexofenadine, the $\mathrm{p}$-values were 0.2423 for $\ln \left(\mathrm{AUC}_{0-\mathrm{t}}\right)$, 0.2549 for $\ln \left(\mathrm{AUC}_{0-\infty}\right)$, and 0.4728 for $\ln \left(\mathrm{C}_{\max }\right)$, and for montelukast, the $\mathrm{p}$-values were 0.6679 for $\ln \left(\mathrm{AUC}_{0-\mathrm{t}}\right)$,

Table 1 Demographic characteristics.

\begin{tabular}{lcc}
\hline Parameter $(\mathrm{n}=77)$ & Mean & SD \\
\hline Age $($ years $)$ & 25.68 & 6.24 \\
Height $(\mathrm{m})$ & 1.65 & 0.08 \\
Weight $(\mathrm{kg})$ & 64.55 & 8.92 \\
BMI $\left(\mathrm{kg} / \mathrm{m}^{2}\right)$ & 23.5 & 2.16 \\
\hline
\end{tabular}

n, number; SD, standard deviation; m, meters; $\mathrm{kg}$, kilograms.

Table 2 Pharmacokinetic parameters of fexofenadine and montelukast from test and reference products.

\begin{tabular}{|c|c|c|c|c|c|c|c|c|}
\hline \multirow[t]{3}{*}{ Parameter (Unit) } & \multicolumn{4}{|c|}{ Fexofenadine $(n=77)$} & \multicolumn{4}{|c|}{ Montelukast $(\mathrm{n}=77)$} \\
\hline & \multicolumn{2}{|c|}{ Reference } & \multicolumn{2}{|r|}{ Test } & \multicolumn{2}{|c|}{ Reference } & \multicolumn{2}{|r|}{ Test } \\
\hline & Mean & $( \pm \mathrm{SD})$ & Mean & $( \pm S D)$ & Mean & $( \pm \mathrm{SD})$ & Mean & $( \pm \mathrm{SD})$ \\
\hline $\operatorname{AUC}_{0-\mathrm{t}}\left(\mathrm{ng} / \mathrm{mL}^{*} \mathrm{~h}\right)$ & 2145.799 & $( \pm 1077.646)$ & 1989.35 & $( \pm 977.377)$ & 1619.151 & $( \pm 676.638)$ & 1672.533 & $( \pm 712.287)$ \\
\hline $\mathrm{AUC}_{0-\infty}\left(\mathrm{ng} / \mathrm{mL}^{*} \mathrm{~h}\right)$ & 2228.951 & $( \pm 1094.014)$ & 2080.045 & $( \pm 988.172)$ & 1849.535 & $( \pm 1459.149)$ & 1761.885 & $( \pm 733.498)$ \\
\hline $\mathrm{C}_{\max }(\mathrm{ng} / \mathrm{mL})$ & 376.441 & $( \pm 202.552)$ & 368.247 & $( \pm 190.075)$ & 270.472 & $( \pm 124.419)$ & 273.8 & $( \pm 113.817)$ \\
\hline Parameter (Unit) & \multicolumn{2}{|c|}{ Median (range) } & \multicolumn{2}{|c|}{ Median (range) } & \multicolumn{2}{|c|}{ Median (range) } & \multicolumn{2}{|c|}{ Median (range) } \\
\hline $\operatorname{Ke}(1 / \mathrm{h})$ & 0.13 & $(0.022,0.322)$ & 0.137 & $(0.022,0.355)$ & 0.129 & $(0.002,0.341)$ & 0.129 & $(0.049,0.432)$ \\
\hline$t_{1 / 2}(h)$ & 5.326 & $(2.148,30.885)$ & 5.044 & $(1.951,30.911)$ & 5.356 & $(2.036,272.054)$ & 5.366 & $(1.602,14.071)$ \\
\hline$t_{\max }(h)$ & 2.66 & $(1,5.066)$ & 3 & $(1,6)$ & 3.66 & $(1,8)$ & 3.66 & $(1.33,6)$ \\
\hline
\end{tabular}

Note: Arithmetic mean, SD, Standard deviation.

Table 3 Geometric least square means of test and reference products of fexofenadine.

\begin{tabular}{|c|c|c|c|c|c|c|}
\hline \multirow[t]{2}{*}{ Parameter (Unit) } & \multicolumn{2}{|c|}{$\begin{array}{c}\text { Geometric least squares } \\
\text { means }(n=77)\end{array}$} & \multirow[t]{2}{*}{ Intrasubject CV\% } & \multirow[t]{2}{*}{ Test/Reference \% } & \multicolumn{2}{|c|}{$90 \% \mathrm{Cl}$} \\
\hline & Reference & Test & & & & \\
\hline $\mathrm{AUC}_{0-\mathrm{t}}\left(\mathrm{ng} / \mathrm{ml}^{*} \mathrm{~h}\right)$ & 1867.7948 & 1766.9247 & 29.1788 & 94.59 & 87.612 & 102.144 \\
\hline $\mathrm{AUC}_{0-\infty}^{0-t}\left(\mathrm{ng} / \mathrm{ml}^{*} \mathrm{~h}\right)$ & 1957.0566 & 1861.6752 & 27.5198 & 95.12 & 88.471 & 102.282 \\
\hline $\mathrm{C}_{\max }(\mathrm{ng} / \mathrm{ml})$ & 325.6306 & 324.3628 & 32.8305 & 99.61 & 91.413 & 108.544 \\
\hline
\end{tabular}

The geometric least square means are presented as antilog means. 
Table 4 Geometric least square means of test and reference products of montelukast.

\begin{tabular}{|c|c|c|c|c|c|c|}
\hline \multirow[t]{2}{*}{$\begin{array}{l}\text { Parameter } \\
\text { (unit) }\end{array}$} & \multicolumn{2}{|c|}{$\begin{array}{c}\text { Geometric least squares } \\
\text { means }(n=77)\end{array}$} & \multirow[t]{2}{*}{ Intrasubject CV\% } & \multirow[t]{2}{*}{ Test/Reference \% } & \multirow[t]{2}{*}{$90 \%$} & \\
\hline & Reference & Test & & & & \\
\hline $\mathrm{AUC}_{0-\mathrm{t}}\left(\mathrm{ng} / \mathrm{ml}^{*} \mathrm{~h}\right)$ & 1488.1401 & 1521.495 & 22.1086 & 102.2 & 96.418 & 108.416 \\
\hline $\mathrm{AUC}_{0-\infty}\left(\mathrm{ng} / \mathrm{ml}^{*} \mathrm{~h}\right)$ & 1616.1098 & 1611.803 & 25.3442 & 99.73 & 93.273 & 106.642 \\
\hline $\mathrm{C}_{\max }(\mathrm{ng} / \mathrm{ml})$ & 243.58963 & 248.8821 & 28.6665 & 102.2 & 94.749 & 110.178 \\
\hline
\end{tabular}

The geometric least square means are presented as antilog means.

0.4705 for In $\left(\mathrm{AUC}_{0-\infty}\right)$, and 0.1319 for $\ln \left(\mathrm{C}_{\max }\right)$. Regarding the period factor, the $\mathrm{p}$-values were 0.3254 for $\ln \left(\mathrm{AUC}_{0-\mathrm{t}}\right)$, 0.2697 for $\ln \left(\mathrm{AUC}_{0-\infty}\right)$, and 0.1319 for $\ln \left(\mathrm{C}_{\max }\right)$ for fexofenadine, and for montelukast, the $\mathrm{p}$-values were 0.4758 for In $\left(\mathrm{AUC}_{0-\mathrm{t}}\right), 0.8670$ for $\ln \left(\mathrm{AUC}_{0-\infty}\right)$, and 0.3045 for $\ln \left(\mathrm{C}_{\max }\right)$, and the factor formulation $\mathrm{p}$-values were 0.2270 for $\ln \left(A \cup C_{0-t}\right)$, 0.2489 for $\ln \left(\mathrm{AUC}_{0-\infty}\right)$, and 0.9242 for $\ln \left(\mathrm{C}_{\max }\right)$ for fexofenadine, and for montelukast, the $\mathrm{p}$-values were 0.5248 for $\ln$ $\left(\mathrm{AUC}_{0-\mathrm{t}}\right), 0.9455$ for $\ln \left(\mathrm{AUC}_{0-\infty}\right)$, and 0.6269 for $\ln \left(\mathrm{C}_{\max }\right)$.

The mean plasma concentrations after administration of the fexofenadine and montelukast reference and test products are reported in Figure 1 and Figure 2, respectively.

\section{Tolerability}

During the development of the study, the research subjects were constantly monitored, and the aforementioned safety measures, good clinical practices, and pharmacovigilance were applied. Vital signs and/or the studied parameters were recorded according to the frequencies established in the protocol.

Changes in vital signs recorded at the times established in the protocol were not clinically significant. Some extreme values and fluctuations over time were noted but were not relevant.

No adverse events occurred from the time of signing the informed consent to the time of discharge from the research facilities.

The additives used in the preparation of the tablets are presented in Supplementary Material 1. The additive profiles differed slightly; however, no considerable biological effects were reported in the study, or in the stability tests performed, presented in Supplementary Material 2.

\section{Discussion}

The results of this study demonstrate the comparative bioavailability of the fixed-dose combination tablet containing fexofenadine $120 \mathrm{mg}$ and montelukast $10 \mathrm{mg}$, with the components administered separately at the same dose, in healthy patients. The $90 \% \mathrm{Cls}$ of the logarithmically transformed $\mathrm{AUC}_{0-\mathrm{t}}, \mathrm{AUC}_{0-\infty}$, and $\mathrm{C}_{\max }$ values were within the range of acceptability of $80 \%$ to $125 \%$ according to the requirements of the Guideline on The Investigation of Bioequivalence of the European Medicines Agency ${ }^{20}$ and the norm NOM-177-SSA1-2013. ${ }^{21}$

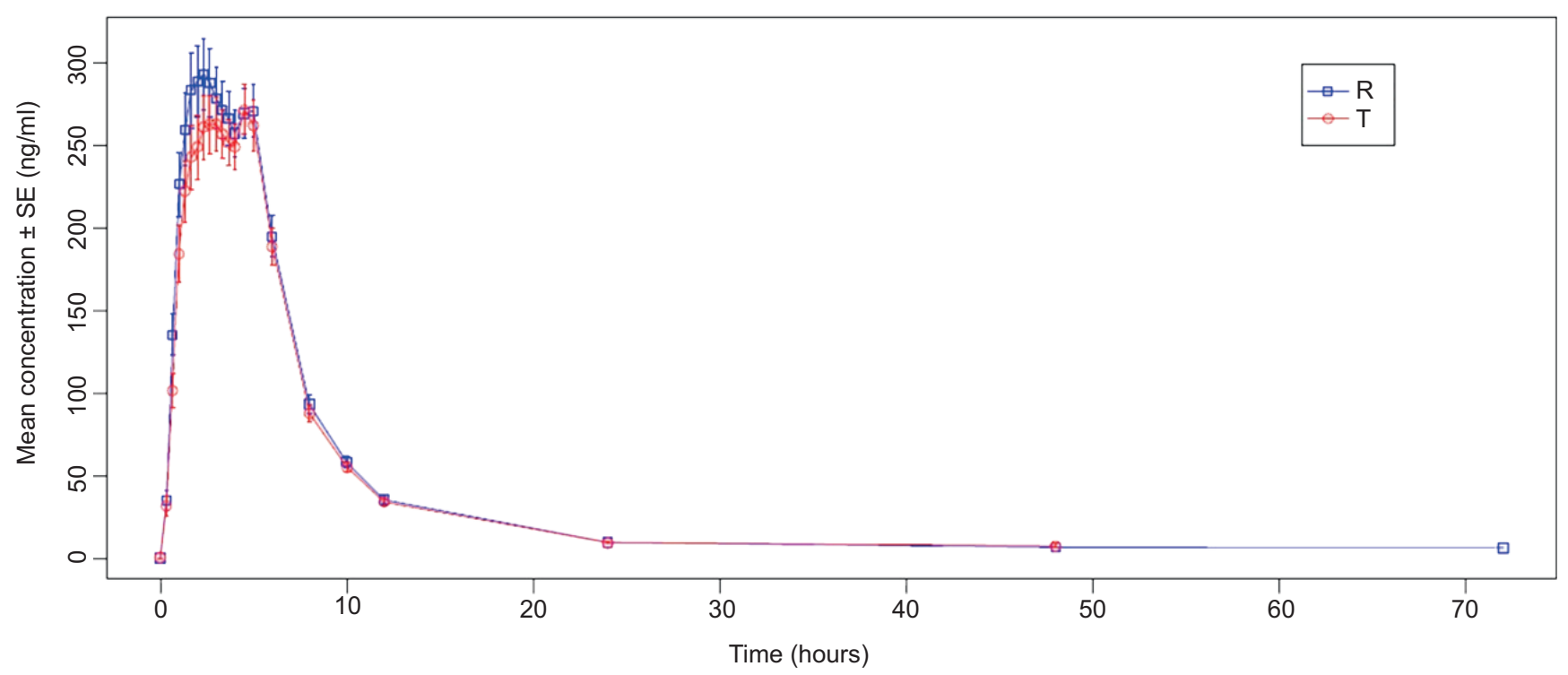

Figure 1 Mean concentrations of fexofenadine after administration of the test and reference products. R, reference; $\mathrm{T}$, test. 


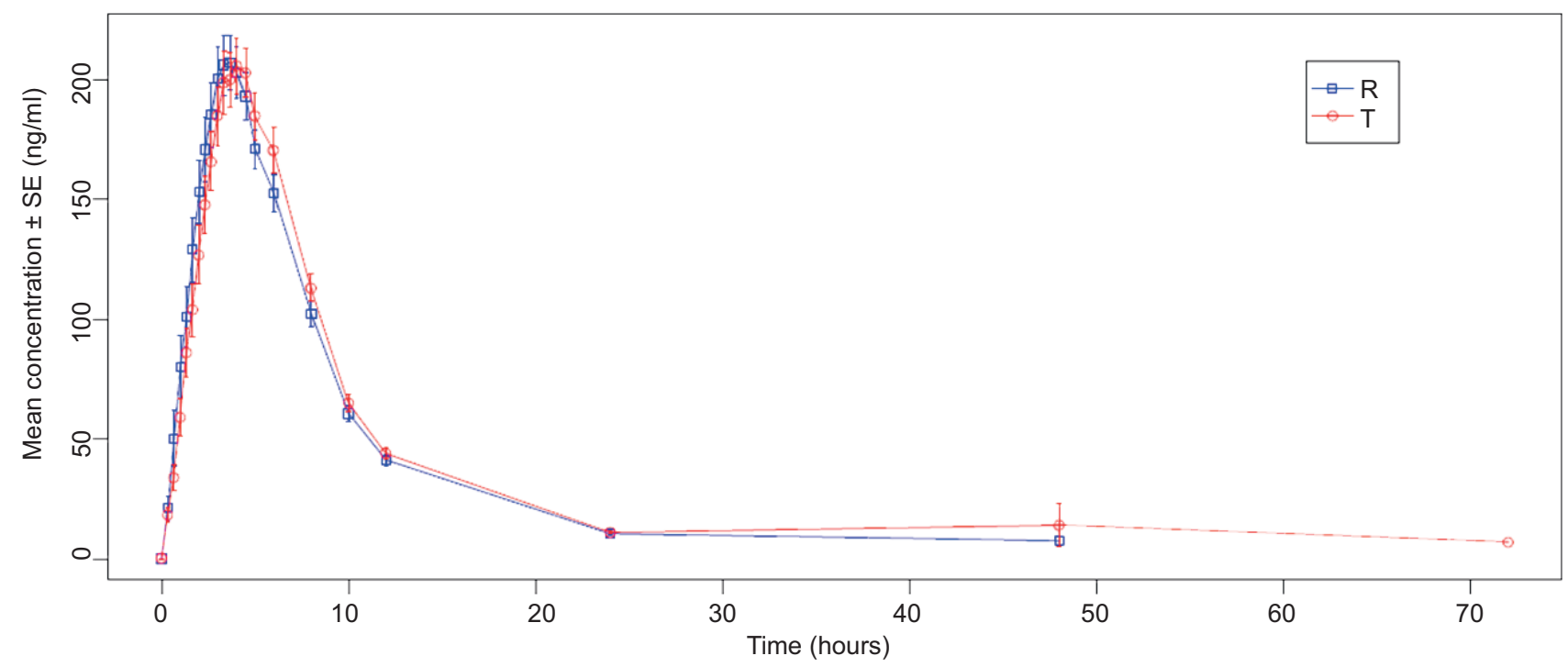

Figure 2 Mean concentrations of montelukast after administration of the test and reference products. R, reference; T, test.

The safety of fexofenadine ${ }^{5}$ and montelukast ${ }^{4}$ has been previously assessed, with both drugs showing safety profiles similar to placebo. Studies have been conducted to evaluate the efficacy of the fixed-dose combination of $120 \mathrm{mg}$ of fexofenadine and $10 \mathrm{mg}$ of montelukast administered once a day for 14 days, and a significant reduction in allergic rhinitis symptoms has been demonstrated. ${ }^{7}$ In the study by Cingi et al., fexofenadine and montelukast were administered concomitantly for 21 days during the spring season when pollen levels are high for comparison with fexofenadine alone and fexofenadine plus placebo. The results showed that the combined treatment was significantly more effective in nasal congestion reduction compared to the other treatments.

The results are consistent with those obtained in the study by Walekar et al. ${ }^{11}$ in which the bioequivalence of the fixed-dose combination and the medications administered concomitantly was established based on the $90 \% \mathrm{Cls}$ of the geometric means of the logarithms of the parameters $A \cup C_{0-t}, A U C_{0-\infty}$, and $C_{\text {max }}$, which were within the range of $80 \%$ to $125 \%$.

\section{Conclusion}

In this study, the fixed-dose combination of fexofenadine $120 \mathrm{mg}$ and montelukast $10 \mathrm{mg}$, and these medications administered concomitantly met the regulatory criteria for bioequivalence in healthy volunteers assessed under fasting conditions. The fixed-dose combination tablet may be considered a new alternative for the treatment of allergic rhinitis and may help patients to control their symptoms and improve therapeutic adherence.

\section{Acknowledgements}

The authors would like to thank Beatrice Bois-De-Fer and Aurore Allard for their advice and critical review of this manuscript. Editorial support was provided by Ella Palmer, PhD, CMPP and Kezia Pittaway, MSc of inScience Communications, Springer Healthcare Ltd, UK, and was funded by Sanofi.

\section{Funding}

The study was funded by Sanofi Aventis de Mexico S.A. de C.V who had a role in all aspects including study design, collection, analysis and interpretation of data, writing of the report, and in the decision to submit the article for publication.

\section{Author contributions}

EPG was involved in conceptualization and design of the study, data acquisition and analysis, manuscript revision, and final approval; MG-S and MEGP were responsible for data analysis, manuscript drafting, revision, and final approval; VCM and GSC contributed to the design of the study, manuscript revision, and final approval.

\section{Ethics approval and consent to participate}

This study was approved by the Ethics Review Committee of 19-CEl-009-20160729.

The informed consent was obtained from all participants, as we sought permission from the patients before data collection. The procedures followed were in accordance with the ethical standards of Helsinki Declaration.

\section{Consent for publication}

Not applicable. 


\section{Competing interests}

The authors VC-M and GS-C are employees of Sanofi Aventis de Mexico S.A. de C.V.

No conflict of interest from iPharma members.

\section{References}

1. Lehman JM, Blaiss MS. Selecting the optimal oral antihistamine for patients with allergic rhinitis. Drugs. 2006;66:23092319. https://doi.org/10.2165/00003495-200666180-00004

2. Cingi C, Gunhan K, Gage-White L, Unlu H. Efficacy of leukotriene antagonists as concomitant therapy in allergic rhinitis. Laryngoscope. 2010;120:1718-1723. https://doi.org/10.1002/ lary.20941

3. Çobanoğlu B, Toskala E, Ural A, Cingi C. Role of leukotriene antagonists and antihistamines in the treatment of allergic rhinitis. Curr Allergy Asthma Rep. 2013;13:203-208. https:// doi.org/10.1007/s11882-013-0341-4

4. Lagos JA, Marshall GD. Montelukast in the management of allergic rhinitis. Ther Clin Risk Manag. 2007;3:327-332. https:// doi.org/10.2147/tcrm.2007.3.2.327

5. Simpson K, Jarvis B. Fexofenadine: a review of its use in the management of seasonal allergic rhinitis and chronic idiopathic urticaria. Drugs. 2000;59:301-321. https://doi. org/10.2165/00003495-200059020-00020

6. Compalati E, Baena-Cagnani R, Penagos M, Badellino $H$, Braido F, Gómez RM, et al. Systematic review on the efficacy of fexofenadine in seasonal allergic rhinitis: a meta-analysis of randomized, double-blind, placebo-controlled clinical trials. Int Arch Allergy Immunol. 2011;156:1-15. https://doi. org/10.1159/000321896

7. Naik MM, Nayak A, Khandeparkar P, Mukaddam QI. Efficacy and safety of montelukast plus fexofenadine fixed dose combination in allergic rhinitis: results of post-marketing study in India. Indian Med Gazette. 2013;8:314-318.

8. Mahatme MS, Dakhale GN, Tadke K, Hiware SK, Dudhgaonkar SD, Wankhede S. Comparison of efficacy, safety, and cost-effectiveness of montelukast-levocetirizine and montelukast-fexofenadine in patients of allergic rhinitis: a randomized, double-blind clinical trial. Indian J Pharmacol. 2016;48:649-653. https://doi.org/10.4103/0253-7613.194854

9. Gupta V, Matreja PS. Efficacy of montelukast and levocetirizine as treatment for allergic rhinitis. J Aller Ther. 2010;1:103. https://doi.org/10.4172/2155-6121.1000103

10. Ciebiada M, Gorska-Ciebiada M, Gorski P. Fexofenadine with either montelukast or a low-dose inhaled corticosteroid (fluticasone) in the treatments of patients with persistent allergic rhinitis and newly diagnosed asthma. Arch Med Sci. 2009;5:564-569.

11. Walekar A, Chodankar D, Naqvi M, Trivedi C. Assessment of bioequivalence of fexofenadine and montelukast fixed dose combination tablet versus separate formulations of the individual components at the same dose levels. Indian J Pharm Sci. 2017;78:651-656. https://doi.org/10.4172/ pharmaceutical-sciences.1000164

12. Mendoza L, Begany P, Dyrhonova M, Emritte N, Svobodova X. Bioequivalence of two fexofenadine formulations in healthy human volunteers after single oral administration. Biomed Pap Med Fac Univ Palacky Olomouc Czech Repub. 2007;151:65-67. https://doi.org/10.5507/bp.2007.011

13. Public assessment report decentralised procedure MONTELUKAST 10MG film-coated tablets UK/H/2199/001/ DC UK licence no: PL 04416/0946 Sandoz Limited. https:// mri.cts-mrp.eu/human/downloads/DE_H_5912_001_PAR.pdf. Available at: Last accessed April 2021

14. Luo J, Imai H, Ohyama T, Hashimoto S, Hasunuma T, Inoue $Y$, et al. The pharmacokinetic exposure to fexofenadine is volume-dependently reduced in healthy subjects following oral administration with apple juice. Clin Transl Sci. 2016;9:201206. https://doi.org/10.1111/cts. 12400

15. R Core Team. R: a language and environment for statistical computing. Vienna, Austria: R Foundation for Statistical Computing; 2011. Available at: http://www.R-project.org/.

16. Bolton S, Bon C. Pharmaceutical statistics: practical and clinical applications. 4th ed., rev.expanded. New York: M. Dekker; 2004.

17. Westlake WJ. Symmetrical confidence intervals for bioequivalence trials. Biometrics. 1976;32:741-744. https://doi. org/10.2307/2529259

18. Schuirmann DJ. A comparison of the two one-sided tests procedure and the power approach for assessing the equivalence of average bioavailability. J Pharmacokinet Biopharm. 1987;15:657-680. https://doi.org/10.1007/BF01068419

19. Chow S-C, Liu J. Design and analysis of bioavailability and bioequivalence studies. 3rd ed. Boca Raton, FL: CRC Press; 2009.

20. European Medicines Agency Committee for Medicinal Products for Human Use. Guideline on the investigation of bioequivalence. 2010. Available at: https://www. ema.europa.eu/en/documents/scientific-guideline/ guideline-investigation-bioequivalence-rev1_en.pdf.

21. Secretaría de Salud, Comisión Federal para la Protección de riesgos Sanitarios. Norma Oficial Mexicana NOM-177-SSA1-2013. Diario Oficial de la Federación. Available at: http://www.dof. gob.mx/nota_detalle.php?codigo=5314833\&fecha=20/09/2013. Published September 20, 2013. 


\section{Supplementary Materials}

Supplementary Material 1. Additives used in tablet formation

\section{Drug}

Fexofenadine hydrochloride $120 \mathrm{mg}$ (amount is adjusted according to titration $/ 2 \%$ excess added)

\section{Additives}

Pregelatinized starch $120 \mathrm{mg}$

Microcrystalline cellulose $81 \mathrm{mg}$ PH101

Microcrystalline cellulose $52 \mathrm{mg}$ PH102

Croscarmellose $24 \mathrm{mg}$

Magnesium stearate $3 \mathrm{mg}$

Purified water cs (evaporates during processing)

\section{Second layer}

\section{Drug}

Montelukast sodium equivalent to Montelukast $10 \mathrm{mg}$ (the amount is adjusted according to the titration/an excess of $2 \%$ is added).

\section{Additives}

Lactose monohydrate $150.600 \mathrm{mg}$

Microcrystalline cellulose $15 \mathrm{mg}$ PH112

Microcrystalline cellulose 15 mg PH 101

Croscarmellose $6 \mathrm{mg}$

Hydroxypropylcellulose $2 \mathrm{mg}$

Magnesium Stearate $0.500 \mathrm{mg}$

Iron oxide yellow $0.500 \mathrm{mg}$ E172

Purified water cs (evaporates during processing)

Supplementary Material 2 Final tablet product specifications

\begin{tabular}{|c|c|c|c|c|c|}
\hline Test & Specification & Reference & Release & Stability & Justification \\
\hline Description & $\begin{array}{l}\text { Oblong, biconvex tablet, } \\
\text { with yellow to dark } \\
\text { yellow coating, engraved } \\
\text { ' } 120 \text { ' on one side and ' } 10 \text { ' } \\
\text { on the other side. }\end{array}$ & $\begin{array}{l}\text { Finished product } \\
\text { specification } \\
\text { and analytical } \\
\text { test procedure, } \\
\text { T-069AMF120, EDITION } \\
\text { No. } 005 \text {. }\end{array}$ & $x$ & $x$ & $\begin{array}{l}\text { Characteristics that } \\
\text { must be fulfilled } \\
\text { according to the } \\
\text { formulation design. }\end{array}$ \\
\hline Average weight & $\begin{array}{l}615.0 \mathrm{mg} \pm 5 \% \\
(584.25-645.75 \mathrm{mg})\end{array}$ & $\begin{array}{l}\text { Finished product } \\
\text { specification } \\
\text { and analytical } \\
\text { test procedure, } \\
\text { T-069AMF120, EDITION } \\
\text { No. } 005 \text {. }\end{array}$ & $x$ & & $\begin{array}{l}\text { Failure to comply with } \\
\text { these specifications } \\
\text { would consequently } \\
\text { have an impact on drug } \\
\text { trial compliance. }\end{array}$ \\
\hline $\begin{array}{l}\text { Weight } \\
\text { uniformity }\end{array}$ & $\begin{array}{l}\text { No more than two } \\
\text { individual weights deviate } \\
\text { more than } 5 \% \text { from the } \\
\text { average and none deviate } \\
\text { more than } 10 \% \text {. }\end{array}$ & $\begin{array}{l}\text { Finished product } \\
\text { specification } \\
\text { and analytical } \\
\text { test procedure, } \\
\text { T-069AMF120, EDITION } \\
\text { No. } 005 \text {. }\end{array}$ & $x$ & & \\
\hline Disintegration & Maximum 30 minutes & $\begin{array}{l}\text { Finished product } \\
\text { specification } \\
\text { and analytical } \\
\text { test procedure, } \\
\text { T-069AMF120, EDITION } \\
\text { No. } 005 \text {. }\end{array}$ & $x$ & & $\begin{array}{l}\text { Test indirectly related } \\
\text { to drug dissolution. Both } \\
\text { the formulation process } \\
\text { variables and storage } \\
\text { conditions can have an } \\
\text { effect on the test. }\end{array}$ \\
\hline \multicolumn{6}{|l|}{ Identification } \\
\hline $\begin{array}{l}\text { a. Fexofenadine } \\
\text { HCl by HPLC }\end{array}$ & $\begin{array}{l}\text { The retention time of the } \\
\text { Fexofenadine } \mathrm{HCl} \text { peak } \\
\text { in the chromatogram } \\
\text { of the test solution } \\
\text { corresponds to the } \\
\text { Fexofenadine } \mathrm{HCl} \text { peak in } \\
\text { the chromatogram of the } \\
\text { standard solution }\end{array}$ & $\begin{array}{l}\text { Finished product } \\
\text { specification } \\
\text { and analytical } \\
\text { test procedure, } \\
\text { T-069AMF120, EDITION } \\
\text { No. 005. }\end{array}$ & $x$ & & $\begin{array}{l}\text { Drug identification is } \\
\text { critical for safety and } \\
\text { efficacy. }\end{array}$ \\
\hline $\begin{array}{l}\text { b. Montelukast } \\
\text { by HPLC }\end{array}$ & $\begin{array}{l}\text { The retention time of the } \\
\text { Montelukast peak in the } \\
\text { chromatogram of the test } \\
\text { solution corresponds to } \\
\text { the Montelukast peak in } \\
\text { the chromatogram of the } \\
\text { standard solution. }\end{array}$ & $\begin{array}{l}\text { Finished product } \\
\text { specification } \\
\text { and analytical } \\
\text { test procedure, } \\
\text { T-069AMF120, EDITION } \\
\text { No. } 005 \text {. }\end{array}$ & $x$ & & $\begin{array}{l}\text { Drug identification is } \\
\text { critical for safety and } \\
\text { efficacy. }\end{array}$ \\
\hline
\end{tabular}




\begin{tabular}{|c|c|c|c|c|c|}
\hline Test & Specification & Reference & Release & Stability & Justification \\
\hline \multicolumn{6}{|l|}{ Uniformity of Dose } \\
\hline $\begin{array}{l}\text { a. Fexofenadine } \\
\mathrm{HCl} \\
\text { Stage I (L1 = } \\
15.0) \\
\text { Acceptance } \\
\text { Value (AV) of } 10 \\
\text { units }\end{array}$ & Maximum 15 & $\begin{array}{l}\text { Finished product } \\
\text { specification } \\
\text { and analytical } \\
\text { test procedure, } \\
\text { T-069AMF120, EDITION } \\
\text { No. } 005 \text {. }\end{array}$ & $\mathrm{X}$ & & $\begin{array}{l}\text { Variability in content } \\
\text { uniformity can affect } \\
\text { safety and efficacy. Both } \\
\text { formulation and process } \\
\text { variables can affect } \\
\text { content uniformity. }\end{array}$ \\
\hline \multicolumn{6}{|c|}{$\begin{array}{l}\text { Acceptance value } \\
\text { (AV) of } 30 \\
\text { units } \\
0 \text { Units }<[1-(0.01) \\
\text { (L2)]M } \\
0 \text { Units }<[1+\end{array}$} \\
\hline b. Montelukast & Maximum 15 & $\begin{array}{l}\text { Finished product } \\
\text { specification } \\
\text { and analytical } \\
\text { test procedure, } \\
\text { T-069AMF120, EDITION } \\
\text { No. } 005 \text {. }\end{array}$ & $X$ & & \\
\hline $\begin{array}{l}\text { Water content by } \\
\text { Karl Fischer }\end{array}$ & Informative (\%) & $\begin{array}{l}\text { Finished product } \\
\text { specification } \\
\text { and analytical } \\
\text { test procedure, } \\
\text { T-069AMF120, EDITION } \\
\text { No. } 005 \text {. }\end{array}$ & $\mathrm{X}$ & $x$ & $\begin{array}{l}\text { Generally, water content } \\
\text { can affect degradation } \\
\text { and promote microbial } \\
\text { growth. }\end{array}$ \\
\hline \multicolumn{6}{|l|}{ Dissolution } \\
\hline $\begin{array}{l}\text { a. Fexofenadine } \\
\mathrm{HCl} \\
\mathrm{Q}=80 \%, 30 \\
\text { minutes }\end{array}$ & Minimum $80 \%$ & $\begin{array}{l}\text { Finished product } \\
\text { specification } \\
\text { and analytical } \\
\text { test procedure, } \\
\text { T-069AMF120, EDITION } \\
\text { No. } 005 \text {. }\end{array}$ & $x$ & $x$ & $\begin{array}{l}\text { Failure to meet the } \\
\text { dissolution specification } \\
\text { may affect the } \\
\text { bioavailability of } \\
\text { the drug. Both the } \\
\text { formulation and process }\end{array}$ \\
\hline $\begin{array}{l}\text { b. Montelukast } \\
\mathrm{Q}=70 \%, 30 \\
\text { minutes }\end{array}$ & Mínimum 70\% & $\begin{array}{l}\text { Finished product } \\
\text { specification } \\
\text { and analytical } \\
\text { test procedure, } \\
\text { T-069AMF120, EDITION } \\
\text { No. } 005 \text {. }\end{array}$ & $x$ & $x$ & $\begin{array}{l}\text { variables can affect the } \\
\text { dissolution profile. }\end{array}$ \\
\hline \multicolumn{6}{|l|}{ Assay } \\
\hline $\begin{array}{l}\text { a. Fexofenadine } \\
\mathrm{HCl}\end{array}$ & $\begin{array}{l}114.0-126.0 \mathrm{mg} / \text { tablet } \\
95.0 \%-105.0 \%\end{array}$ & $\begin{array}{l}\text { Finished product } \\
\text { specification and } \\
\text { analytical test procedure, } \\
\text { T-069AMF120, EDITION } \\
\text { No. } 005 \text {. }\end{array}$ & $\mathrm{X}$ & $x$ & $\begin{array}{l}\text { Variability in the trial } \\
\text { can affect safety and } \\
\text { efficacy. }\end{array}$ \\
\hline b. Montelukast & $\begin{array}{l}10.0-11.0 \mathrm{mg} / \text { tablet } \\
90.0 \%-110.0 \%\end{array}$ & $\begin{array}{l}\text { Finished product } \\
\text { specification and } \\
\text { analytical test procedure, } \\
\text { T-069AMF120, EDITION } \\
\text { No. } 005 \text {. }\end{array}$ & $x$ & $x$ & \\
\hline
\end{tabular}




\begin{tabular}{|c|c|c|c|c|c|}
\hline Test & Specification & Reference & Release & Stability & Justification \\
\hline \multicolumn{6}{|c|}{ Fexofenadine HCl-Related Substances } \\
\hline a. Impurity A & $\leq 0.40 \%$ & $\begin{array}{l}\text { Finished product } \\
\text { specification } \\
\text { and analytical } \\
\text { test procedure, } \\
\text { T-069AMF120, EDITION } \\
\text { No. } 005 \text {. }\end{array}$ & $x$ & $x$ & $\begin{array}{l}\text { Degradation products } \\
\text { can have an impact } \\
\text { on safety and must } \\
\text { be quantified and } \\
\text { monitored. }\end{array}$ \\
\hline $\begin{array}{l}\text { b. Decarboxylated } \\
\text { degradation }\end{array}$ & $\leq 0.15 \%$ & $\begin{array}{l}\text { Finished product } \\
\text { specification } \\
\text { and analytical } \\
\text { test procedure, } \\
\text { T-069AMF120, EDITION } \\
\text { No. } 005 \text {. }\end{array}$ & $x$ & $x$ & \\
\hline $\begin{array}{l}\text { c. Any individual } \\
\text { impurity }\end{array}$ & $\leq 0.20 \%$ & $\begin{array}{l}\text { Finished product } \\
\text { specification } \\
\text { and analytical } \\
\text { test procedure, } \\
\text { T-069AMF120, EDITION } \\
\text { No. } 005 \text {. }\end{array}$ & $x$ & $x$ & \\
\hline d. Impurity Sum & $\leq 0.50 \%$ & $\begin{array}{l}\text { Finished product } \\
\text { specification } \\
\text { and analytical } \\
\text { test procedure, } \\
\text { T-069AMF120, EDITION } \\
\text { No. } 005 \text {. }\end{array}$ & $x$ & $x$ & \\
\hline \multicolumn{6}{|c|}{ Montelukast-Related Substances } \\
\hline $\begin{array}{l}\text { a. Sulfoxide } \\
\text { impurity }\end{array}$ & $\leq 2.0$ & $\begin{array}{l}\text { Finished product } \\
\text { specification } \\
\text { and analytical } \\
\text { test procedure, } \\
\text { T-069AMF120, EDITION } \\
\text { No. } 005 \text {. }\end{array}$ & $x$ & $x$ & $\begin{array}{l}\text { Degradation products } \\
\text { can have an impact } \\
\text { on safety and must } \\
\text { be quantified and } \\
\text { monitored. }\end{array}$ \\
\hline $\begin{array}{l}\text { b. Hydroxy } \\
\text { Impurity }\end{array}$ & $\leq 0.2$ & $\begin{array}{l}\text { Finished product } \\
\text { specification } \\
\text { and analytical } \\
\text { test procedure, } \\
\text { T-069AMF120, EDITION } \\
\text { No. } 005 \text {. }\end{array}$ & $x$ & $x$ & \\
\hline $\begin{array}{l}\text { c. Cis-isomer } \\
\text { impurity }\end{array}$ & $\leq 0.2$ & $\begin{array}{l}\text { Finished product } \\
\text { specification } \\
\text { and analytical } \\
\text { test procedure, } \\
\text { T-069AMF120, EDITION } \\
\text { No. } 005 \text {. }\end{array}$ & $x$ & $x$ & \\
\hline d. F impurity & $\leq 0.2$ & $\begin{array}{l}\text { Finished product } \\
\text { specification } \\
\text { and analytical } \\
\text { test procedure, } \\
\text { T-069AMF120, EDITION } \\
\text { No. } 005 \text {. }\end{array}$ & $x$ & $x$ & \\
\hline $\begin{array}{l}\text { e. Any other } \\
\text { impurity }\end{array}$ & $\leq 0.2$ & $\begin{array}{l}\text { Finished product } \\
\text { specification } \\
\text { and analytical } \\
\text { test procedure, } \\
\text { T-069AMF120, EDITION } \\
\text { No. } 005 \text {. }\end{array}$ & $x$ & $x$ & \\
\hline
\end{tabular}




\begin{tabular}{|c|c|c|c|c|c|}
\hline Test & Specification & Reference & Release & Stability & Justification \\
\hline f. Total impurity & $\leq 3.0$ & $\begin{array}{l}\text { Finished product } \\
\text { specification } \\
\text { and analytical } \\
\text { test procedure, } \\
\text { T-069AMF120, EDITION } \\
\text { No. } 005 \text {. }\end{array}$ & $X$ & $X$ & \\
\hline $\begin{array}{l}\text { Identification } \\
\text { test for ferric } \\
\text { oxide }\end{array}$ & Positive & $\begin{array}{l}\text { Finished product } \\
\text { specification } \\
\text { and analytical } \\
\text { test procedure, } \\
\text { T-069AMF120, EDITION } \\
\text { No. } 005 \text {. }\end{array}$ & $x$ & & $\begin{array}{l}\text { Test performed to } \\
\text { verify the presence } \\
\text { of ferric oxide as a } \\
\text { coloring lacquer. }\end{array}$ \\
\hline \multicolumn{6}{|l|}{ Microbiology } \\
\hline $\begin{array}{l}\text { Aerobic } \\
\text { mesophilic } \\
\text { organisms }\end{array}$ & Maximum $10^{3}$ & FEUM 11ed & $x$ & $x$ & \multirow{3}{*}{$\begin{array}{l}\text { Failure to comply with } \\
\text { microbial limits would } \\
\text { have an impact on } \\
\text { patient health. }\end{array}$} \\
\hline $\begin{array}{l}\text { Filamentous } \\
\text { fungi and yeast } \\
\text { counts }\end{array}$ & Maximum $10^{2}$ & FEUM 11ed & $x$ & $x$ & \\
\hline Escherichia coli & Absence & FEUM 11ed & $x$ & $x$ & \\
\hline
\end{tabular}

